\title{
Impact of Self-Help Group Formation on Social Indicators of Sustainability
}

\author{
Surinder Singh ${ }^{1}$ and B.S Hansra ${ }^{2}$
}

\begin{abstract}
Vegetable production has emerged as an important source of farm income from small farms in hilly states like Himachal Pradesh in India. Various researchers have studied agricultural sustainability taking into consideration three dimensions i.e. economic, environmental and social. Keeping in view the importance of the social sustainability which measures extent of social capability of farming system, present study was conducted in Himachal Pradesh to find out the ways to strengthen farm sustainability. Farm sustainability of self-help group member farmers and non-member farmers was studied and compared. Study revealed that the social sustainability of vegetable growers who were members of self-help groups was significantly higher when compared to non-member farmers
\end{abstract}

Keywords: Social sustainability; Social indicators; Vegetable farms; Self-help group; Himachal Pradesh

\section{INTRODUCTION}

Agriculture sustainability is meeting the present needs of agriculture without compromising the resources of future generation. Various researchers have studied sustainability under three dimensions viz., environmental, economic and social. Out of these three pillars of sustainability, social dimension has got minimum attraction of the researchers as with the concept of sustainability, people mostly think about the environment or economic sustainability.

More attention is now being given to the idea of social sustainability, which until recently had been sorely neglected. Social sustainability often is broadly defined to include community impacts, general human rights, social justice, and labor rights and treatment.

Agricultural systems are embedded in wider social, ecological, institutional, and market networks that influence their continuity, change and impacts. Social sustainability is about identifying and managing agricultural impacts, both positive and negative, on people. Social sustainability which measures extent of social capability of farming system, matters more at the level of the farm community as farmers can play the key role in sustainability.

In recent years, vegetable production has emerged as an important economic activity

1. PhD Scholar, School of Agriculture, IGNOU, New Delhi and 2. Professor Emeritus, Amity International University Noida, Uttar Pradesh 
in small farms of Himachal Pradesh. Many hill farmers have diversified their farms seeking more profit from small farms paving way to new problems associated with hill agriculture. Since discussions of agricultural sustainability often overlook the social dimension which measures extent of social capability of farming system, the present study was conducted with the following objectives.

1. To study impact of self-help groups on various indicators of social sustainablitlity.

2. To compare social sustainability index of SHG (Self-Help Group) members' and nonmembers' vegetable farms.

\section{METHODOLOGY}

The study was conducted during 2014-2017 in the state of Himachal Pradesh in India covering six districts viz., Kangra, Chamba, Mandi, Kullu, Solan and Shimla which were randomly selected from three divisions of the state. In each district, five vegetable farming based Self- Help Groups (SHGs) were selected covering a total of $30 \mathrm{SHGs}$ in six districts. From each selected Self-Help group five members were selected randomly. Thus, a total 150 group members were selected and interviewed. To make a comparison on social sustainability, 150 non-member vegetable growers were selected randomly from the adjoining village. Thus data were collected from 300 farmers in the state. Data on various sustainability indicators finalised after consulting 40 judges in the field of vegetable production, economics, agricultural extension were collected through direct interview and was analysed using various statistical tools. Social Sustainability Index was prepared considering relative weightage of selected indicators.

\section{FINDINGS AND DISCUSSION}

After detailed deliberations with the experts, relevant social sustainability indicators like community relationship of the farmers, knowledge on vegetable farming, adoption of improved farming practices, access to resources and support services were considered underlying factors to measure social sustainability of vegetable farms.

\section{Community Relations}

A stronger community relationship enhances one's special mobility and similarly has effect on others in the society. The support received from the community can significantly impact farming activities of farmers. It is one of the important indicators of social sustainability and it is imperative to examine a farmer's relationship to his or her community through community involvement and subsequently involvement of community on farms. The data collected on this variable are presented in Table 1.

It reveals that majority of members were having medium level of community relationship (2), Among non-members, majority of non- members were found having (42.00 per cent) low community relations. The mean community relationship score for members (1.56) was significantly higher than non-members (1.02) and probable reason for higher community relationship for members might be attributed to the fact that SHG influenced members' involvement in informal/ formal organisation and vice-versa. These results are in line with Bariya et al (2017). 
Table 1.

Comparison of Social Sustainability Indicators for SHG Members and Non-member farmers in Himachal Pradesh

\begin{tabular}{|c|c|c|c|c|c|c|}
\hline SI. No. & $\begin{array}{l}\text { Indicator of social } \\
\text { sustainability }\end{array}$ & $\begin{array}{c}\text { SHG } \\
\text { Member } \\
(n=150)\end{array}$ & $\begin{array}{l}\text { Mean } \\
\text { value }\end{array}$ & $\begin{array}{c}\text { Non- } \\
\text { member } \\
(n=150)\end{array}$ & $\begin{array}{l}\text { Mean } \\
\text { value }\end{array}$ & $Z$ value \\
\hline A & \multicolumn{6}{|c|}{ Community relationship } \\
\hline 1 & No & $22(14.67)$ & \multirow{4}{*}{1.56} & $45(30.00)$ & \multirow{4}{*}{1.02} & \multirow{4}{*}{$4.97^{* *}$} \\
\hline 2 & Low & $41(27.33)$ & & $63(48.00)$ & & \\
\hline 3 & Medium & $62(41.33)$ & & $36(24.00)$ & & \\
\hline 4 & High & $25(16.67)$ & & $6 \quad(04.00)$ & & \\
\hline B & \multicolumn{6}{|c|}{ Knowledge on vegetable farming } \\
\hline 1 & Low & $42(28.00)$ & \multirow[b]{3}{*}{23.33} & $124(82.66)$ & \multirow[b]{3}{*}{28.19} & \multirow{3}{*}{$10.43^{* *}$} \\
\hline 2 & Medium & $72(48.00)$ & & $20(12.37)$ & & \\
\hline 3 & High & $36(24.00)$ & & $6(4.00)$ & & \\
\hline C & \multicolumn{6}{|c|}{ Access to resources and support services } \\
\hline 1 & Less & $4932.67)$ & \multirow[b]{3}{*}{3.30} & $96(64.00)$ & \multirow[b]{3}{*}{2.41} & \multirow[b]{3}{*}{$5.32^{* *}$} \\
\hline 2 & Medium & $72(48.00)$ & & $46(30.67)$ & & \\
\hline 3 & High & $29(19.33)$ & & $8 \quad(5.33)$ & & \\
\hline D & \multicolumn{6}{|c|}{ Adoption of improved vegetable farming practices } \\
\hline 1 & Low & $37(24.67)$ & \multirow{3}{*}{52.82} & $96(64.00)$ & \multirow{3}{*}{38.05} & \multirow{3}{*}{$6.95^{* *}$} \\
\hline 2 & Medium & $71(47.33)$ & & $36(24.00)$ & & \\
\hline 3 & High & $42(28.00)$ & & $18(12.00)$ & & \\
\hline
\end{tabular}

** Significant at $1 \%$ level of significance

(Figures in the parentheses indicate percentage)

\section{Knowledge of Vegetable farming}

Knowledge is the fact or condition of being aware of something, acquaintance with or understanding of a sequence, art or technique, familiarity gained through experience or association. It is the range of one's information or understanding.

Table 1 reveals that majority of the members (48.00 per cent) had medium level of knowledge; followed by 28.00 percent and 24.00 percent of them having low and high level of knowledge respectively. From the same table it is found that majority of nonmembers (82.66 percent) possesses low level of knowledge.

Significantly higher extension contacts, trainings and high community involvements might be the reasons for higher knowledge on vegetable farming by the members. 
Impact of Self-Help Group Formation on Social Indicators of Sustainability

Access to Resources and Support services.

Sustainability of any farming system requires that all members of a society must have access to resources and support services which give them the opportunity to derive a level of well-being above a certain minimum level established by the society.

Table 1 reveals that majority of the members $(48.00$ per cent belonged to medium category followed by less category (32.67 per cent). In case of non-members majority of the respondents ( 64.00 per cent) were found to have less access to resources and support services category followed by medium category (30.67 per cent). The mean access to resources and support services was found significantly higher for members when compared to non-members at one per cent level of significance.

\section{Adoption of Improved Vegetable farming practices}

Adoption of technologies for sustainable farming system is a challenging and dynamic issue for farmers, extension services and policy makers. Farmers adopting sustainable practices can influence other farmers around them to consider adoption as well. The level of adoption of improved vegetable farming practices is presented in Table 1. For adoption level categories, it was observed that most of the SHG members were found to have level of adoption (47.33 per cent) followed by high level adopters (28.00 per cent) whereas in case of nonmembers most of the respondents were found in low adoption category (64.00 per cent). The explanation to this phenomenon might be high extension contacts, SHG finance and significantly higher number of trainings attended by SHG members.

\section{Social Sustainability Index}

Social Sustainability Index (SSI) measures extent of social capability of farming system. The indicators discussed above were used to work out the SSI of vegetable farms of members and non-members. The findings are presented in Table 2.

The SSI of vegetable farms of the members ranged from 0.10 to 0.90 while for nonmembers it varied between 0.05 to 0.91 .

Table 2.

Social Sustainability Index (SSI) of Vegetable Farms

\begin{tabular}{|c|c|c|c|c|c|c|}
\hline \multirow[b]{2}{*}{$\begin{array}{c}\text { Respond- } \\
\text { ents }\end{array}$} & \multicolumn{4}{|c|}{ Level of Sustainability } & \multirow[b]{2}{*}{$\begin{array}{l}\text { Mean } \\
\text { Value }\end{array}$} & \multirow[b]{2}{*}{ Z-value } \\
\hline & $\begin{array}{c}\text { Least } \\
\text { Sustainable } \\
(0-0.25)\end{array}$ & $\begin{array}{c}\text { Moderately } \\
\text { Sustainable } \\
(0.26-0.50)\end{array}$ & $\begin{array}{l}\text { Sustainable } \\
(0.51-0.75)\end{array}$ & $\begin{array}{c}\text { Highly } \\
\text { Sustainable } \\
(0.76-1.00)\end{array}$ & & \\
\hline $\begin{array}{c}\text { Members } \\
(\mathrm{N}=150)\end{array}$ & $\begin{array}{c}7 \\
(4.67)\end{array}$ & $\begin{array}{c}67 \\
(44.00)\end{array}$ & $\begin{array}{c}66 \\
(44.67)\end{array}$ & $\begin{array}{c}10 \\
(6.66)\end{array}$ & 0.50 & \\
\hline $\begin{array}{c}\text { Non- } \\
\text { Members } \\
(\mathrm{N}=150)\end{array}$ & $\begin{array}{c}45 \\
(30.00)\end{array}$ & $\begin{array}{c}67 \\
(44.67)\end{array}$ & $\begin{array}{c}34 \\
(22.67)\end{array}$ & $\begin{array}{c}4 \\
(2.66)\end{array}$ & 0.37 & $6.63^{* *}$ \\
\hline
\end{tabular}

${ }^{* *}$ Significant at $1 \%$ level of significance (Figures in parentheses indicate percentage) 
As evident from Table 2, the mean SSI of members (0.50) had a significant difference at 0.01 percent of probability with that of the non -members (0.37). Majority of members' farms (44.66 percent) were found to be sustainable followed by moderately sustainable $(44.00)$ and highly sustainable (6.66). In case of nonmembers, majority of vegetable farms (44.67) were moderately sustainable followed by least sustainable (30.00 per cent)

The vegetable farms of members were exhibiting higher social sustainability due to higher knowledge, higher adoption level of technologies at farms, involvement in community activities and more extensive contacts with change agents.

\section{CONCLUSION}

Social sustainability is an important pillar of overall sustainability of vegetable farms. In the present study it was proved that self-help group approach can address these needs in a better way as significantly higher community relationship behaviour, better adoption, access to resources, and increased extension contacts were observed for SHG member farmers which ultimately strengthen the social sustainability dimension of vegetable farmers.

Thus, Self-help groups engaged in vegetable farming have the potential to empower their members through the provision of better community relations, knowledge, skill, adoption and effective extension contacts that underpin sustainable vegetable farming in the states like Himachal Pradesh with small land holdings.

\section{REFERENCES}

Bariya, M.K., Chhodvadia, H C., Patel,H., Parmar,S., \& Vyas, J. (2017). Study on Profile Characteristics of Women Self Help Group Members. Journal of Krishi Vigyan, 5(2), 154-159 